Japan. J. Med. Sci. Biol., 19, 1-8, 1966

\title{
TITRATION OF ADENOVIRUS TYPE 12 AND TYPE 18 IN HUMAN EMBRYONIC KIDNEY CELL CULTURES
}

\author{
HiRoto SHIMOJO, Kyoko SAWAMURA, RisAko WADA AND Eiko YOSHIKAWA \\ Department of Enteroviruses, National Institute of Health, Tokyo
}

(Received: December 13th, 1965)

\begin{abstract}
The infectivity of adenovirus type 12 and type 18 could be titrated sensitively and accurately by the use of human embryonic kidney cell cultures. Both tube titration and plaque titration could be used. The detailed techniques of the titrations are described.
\end{abstract}

\section{INTRODUCTION}

Since the discovery of tumor induction in hamsters by adenovirus type 12 (abbreviated as Ad 12) (Trentin, Yabe and Taylor, 1962), many investigators have been concentrating their efforts on the study of Ad 12. The first difficulty encountered in these studies was the titration of the virus. Many investigators used cell lines such as HeLa or KB cells for the titration which showed very low virus titers (Trentin et al., 1962 and many other reports). These studies have brought about a misunderstanding that the virus titer of Ad 12 might be low. Some investigators (Huebner et al., 1963, McBride \& Wiener, 1964) used human embryonic kidney cell cultures (abbreviated as HEK) which showed a high virus titer; but no details of the titration technique were given in their reports. HEK was, moreover, thought difficult to obtain.

The authors had searched for a sensitive and convenient system with which the titration of Ad 12 could be performed. After various trials for more than a year, no satisfactory system except HEK was found for the titration. Their effort was then concentrated on the efficient use of HEK, including the conditions for the freeze-storage of $\mathrm{HEK}$, for the tube titration and for the plaque titration. After these examinations the techniques for the preservation of HEK, tube titration and plaque titration were established.

\section{MATERIALS AND METHODS}

Virus: Ad 12 Huie strain*, harvested from HeLa cell cultures (virus stock \#11) or from HEK (virus stock \#26), was used. Ad $12 \mathrm{DC}$ strain, obtained from American Type Culture Collection, and harvested from HEK (virus stock \#8) or from HEp-2 cell cultures (virus stock \#4), was also used.

Cell culture: HEK was prepared as follows. Kidneys were obtained from maternity hospitals. Immediately after the removal of a kidney from a fetus, the * The strain was given by Dr. Y. Yabe, Okayama University, to whom authors experess their appreciation.

下条寛人・沢村恭子・和田理紗子・吉川映子（国立予防衛生研究所腸内ウイルス部） 
kidney was brought to the laboratory where it was minced with scissors and treated with $0.2 \%$ trypsin (Difco $1: 250$ ) in a flask with a magnetic stirrer at room temperature. The cells were suspended in a growth medium. As the growth medium, LE (Earle's balanced salt solution supplemented with $0.5 \%$ Lactalbumin hydrolysate, Difco) enriched with $10 \%$ bovine serum and adjusted to $0.075 \%$ sodium bicarbonate concentration was used. The cell suspension was divided into two parts. A part was diluted to the concentration of $1-3 \times 10^{5} \mathrm{cell} / \mathrm{s} / \mathrm{ml}$, dispensed in tissue culture containers (tubes, bottles or Petri dishes) and incubated at $36 \mathrm{C}$ for 5 to 7 days, after which confluent monolayers of HEK were formed. The remaining cell suspension was concentrated by centrifugation to contain $1-3 \times 10^{7}$ cells $/ \mathrm{ml}$, to which $1 / 25$ volume of dimethylsulfoxide was added. The concentrated cell suspension was then dispensed in small tubes which were rubber-stoppered, labeled, wrapped with cloths, put into a plastic bag and kept in a freezer (below $-75 \mathrm{C}$, Revco Ultralow Temperature Freezer). After keeping HEK in a frozen state for some time, the tubes were taken out of the freezer and thawed in a water bath. The cells were washed once with the same growth medium as above except for the concentration of sodium bicarbonate of $0.04 \%$ and then resuspended in the growth medium in a concentration of $5 \times 10^{5}$ cells $/ \mathrm{ml}$. The cell suspension was dispensed in tissue culture containers and incubated at $36 \mathrm{C}$ for seven to fourteen days, after which confluent monolayer of HEK was formed. Sometimes it was necessary to change the medium to fresh growth medium containing $\mathrm{NaHCO}_{3}$ at the concentration of $0.075 \%$. The growth of $\mathrm{HEK}$ from a frozen state was rather slow but no difference in the cell conditions in the maintenance medium or in the sensitivity to virus was found between cultures from a fresh kidney and cultures from a frozen state.

Tube titration and plaque titration: Techniques are given in the descriptions of the results.

\section{RESULTS}

\section{Preservability of HEK in a Frozen State}

A preliminary test on the condition of the preservation of HEK in a frozen state (comparison of media, especially concentration of dimethylsulfoxide) established the above method and HEK came to be used at will according to the design of the experiment. The preservability of HEK in a frozen state is shown in Table 1, which summarizes part of the experiences in the laboratory. HEK could be well preserved in a frozen state but it may also be noted that the longer the preservation period lasted, the longer it took to form confluent monolayers. Therefore, it is concluded that the above method of freeze-storage of HEK could be used but that the improvement of the method such as storage in liquid nitorogen might further increase its efficiency.

\section{Tube Titration of Ad 12 and Ad 18 in HEK}

After the formation of confluent monolayers of HEK in tubes, the growth medium was discarded. HEK tubes were then washed once with phosphate buffered saline ( $\mathrm{pH}$ 7.2, abbreviated as PBS) and $1.0 \mathrm{ml}$ of maintenance medium was added to each tube. Eagle's MEM (Eagle, 1959) without addition of any serum and with $0.15 \%$ sodium bicarbonate was used as a maintenance medium. Tubes were inoculated with 
Table 1. Growth of HEK after storage in a frozen state

\begin{tabular}{|c|c|c|c|c|c|c|}
\hline HEK Batch & Storage form & Storage period & \multicolumn{2}{|c|}{$\begin{array}{l}\text { Concentration of } \\
\text { cells seeded }\end{array}$} & \multicolumn{2}{|c|}{ Sheet formation } \\
\hline$\$ 5$ & 1()$^{7}$ cells $/ \mathrm{ml}$ & 16 days & \multicolumn{2}{|c|}{$4 \times 10^{5} \mathrm{cells} / \mathrm{ml}$} & 8 & days \\
\hline Aug. 13, ' $64^{*}$ & $2 \mathrm{ml} /$ tube & $5 \mathrm{~m}$. & $2 \times 10^{5}$ & " & 11 & $"$ \\
\hline \multirow{5}{*}{ Sep. $11, \$ 94$} & \multirow{5}{*}{$\begin{array}{l}10^{7} \text { cells } / \mathrm{ml} \\
3 \mathrm{ml} / \text { tube }\end{array}$} & 23 days & $6 \times 10^{5}$ & $\prime \prime$ & 6 & $" \prime$ \\
\hline & & $1 \mathrm{~m} .5$ days & $5 \times 10^{5}$ & $\prime \prime$ & 8 & $" \prime$ \\
\hline & & $1 " 9 " \prime$ & $4 \times 10^{5}$ & " & 10 & $" \prime$ \\
\hline & & $2 \mathrm{~m}$ & $5 \times 10^{5}$ & $\prime \prime$ & 9 & " \\
\hline & & $4 \mathrm{~m} .8$ days & $3 \times 10^{5}$ & $\prime \prime$ & 14 & $\prime \prime$ \\
\hline \multirow{5}{*}{ Sep. $\stackrel{\# 11}{22,}, 64$} & \multirow{5}{*}{$\begin{array}{c}1.5 \times 10^{7} \text { cells } / \mathrm{ml} \\
2 \mathrm{ml} / \mathrm{tube}\end{array}$} & $1 " \prime 26 " \prime$ & $5 \times 10^{5}$ & $\prime \prime$ & 5 & $\prime \prime$ \\
\hline & & $2 \mathrm{~m}$. & $5.5 \times 10^{5}$ & " & 7 & $\prime \prime$ \\
\hline & & $2 \mathrm{~m} .10$ days & $5 \times 10^{5}$ & $\prime \prime$ & 11 & $\prime \prime$ \\
\hline & & $2 \prime \prime 25 \prime \prime$ & $5 \times 10^{5}$ & $\prime \prime$ & 7 & $\prime \prime$ \\
\hline & & $3\|15\|$ & $3 \times 10^{5}$ & $\prime \prime$ & 9 & $\prime \prime$ \\
\hline
\end{tabular}

* Date of preparation of $\mathrm{HEK}$

$0.2 \mathrm{ml}$ of serial ten-fold dilutions of the virus. Four to ten tubes were used for each dilution. The tubes were then rubber-stoppred tightly and incubated at $36 \mathrm{C}$ for three weeks, during which time the medium was changed to fresh maintenance medium after every week. A typical cytopathic effect (cluster formation of swollen round cells, abbreviated as CPE) was observed at low dilutions after a week and progressed gradually to high dilutions for 18 days. From the result of three weeks' observation, $\mathrm{TCID}_{50}$ was calculated.

The above method was established after an examination of conditions for the tube titration. Of media so far tested, Eagle's MEM and Parker's medium 199 were found satisfactory but LE was unsatisfactry because it could not maintain HEK monolayers for three weeks. The concentration of sodium bicarbonate was one of the critical factors. A low concentration (0.075\%) could maintain HEK for three weeks but suppressed the appearance of CPE. A medium concentration $(0.15 \%)$ was adopted as the routine technique because it could maintain HEK for three weeks and showed a marked CPE. A high concentration (over $0.2 \%$ ) could not maintain HEK for three weeks, though the appearance of CPE was promoted. The addition of chicken or bovine serum enhanced the maintenance of HEK but showed some suppression of the appearance of CPE. The progressions of CPE are shown in Figs. 1 and 2 , in which the curves show $\operatorname{TCID}_{50} / 0.2 \mathrm{ml}$ based on the observation (only a marked $\mathrm{CPE}$ was regarded as being positive) on the indicated days. Keeping the virus inoculated tubes in a roller drum during incubation enhanced the appearance of CPE but it showed a tendency to bring about nonspecific degeneration of cells. Therefore, the roller drum method was not adopted as the routine technique.

\section{Plaque Titration of Ad 12 and Ad 18 in HEK}

After the formation of confluent monolayers of HEK in plaque bottles (2 oz. bottles) or in Petri dishes $\left(60 \mathrm{~mm}\right.$ in diameter, cultured in a $\mathrm{CO}_{2}$ incubator), the growth 


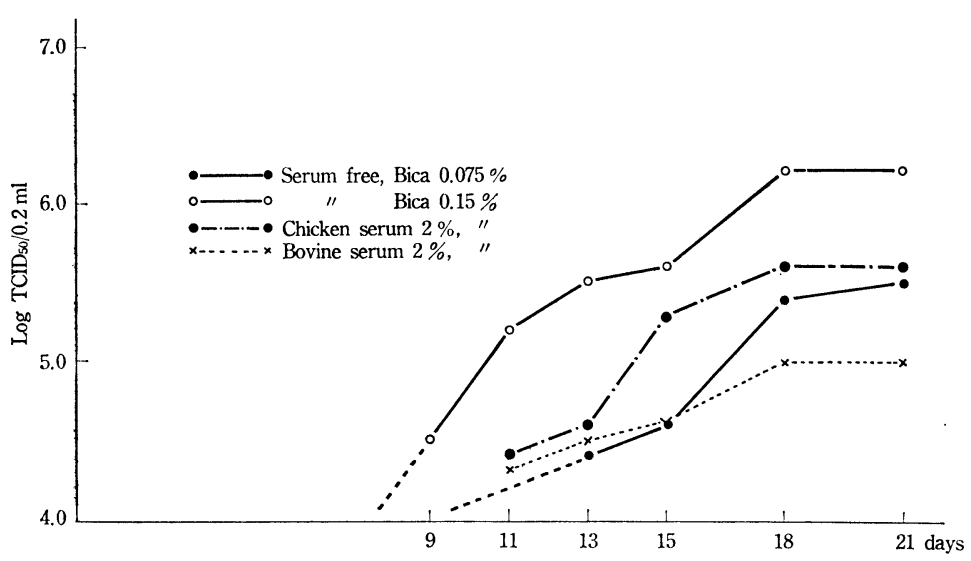

Fig. 1. Tube titration of adenovirus type 12 in HEK. Comparison of maintenance medium

Virus : Adenovirus type 12, Huie strain $¥ 11$

Medium : Eagle's MEM

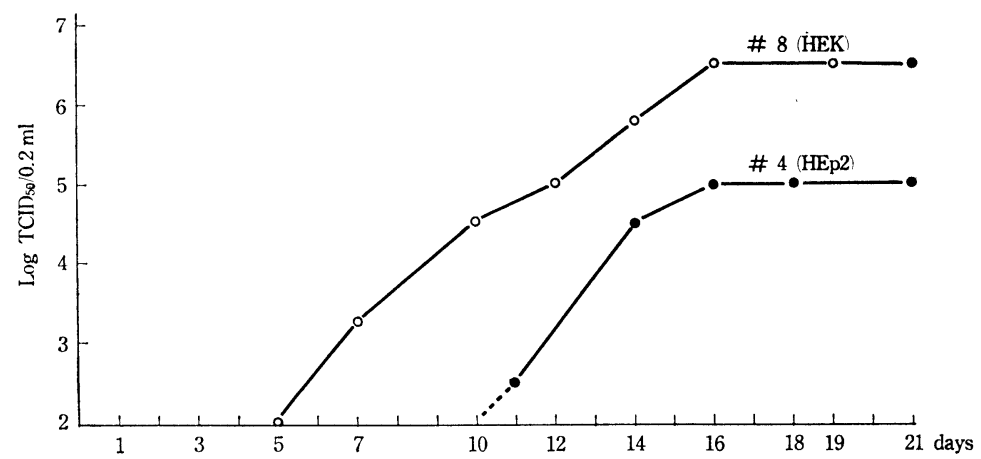

Fig. 2. Tube titration of adenovirus type 18 in HEK.

Virus: Adenovirus type 18, DC strain

Medium: Eagle's MEM, serum free, $\mathrm{NaHCO}_{3} 0.15 \%$

medium was discarded. Cells were washed once with PBS and then inoculated with $0.2 \mathrm{ml}$ of an appropriate dilution of the virus. After adsorption of the virus for $2 \mathrm{hrs}$ at $36 \mathrm{C}$, the fluid remaining in the container was aspirated off and $5.0 \mathrm{ml}$ of an agar overlay was added. The agar overlay consisted of Eagle's MEM, containing inhibitorfree calf serum (5\%), sodium bicarbonate $(0.15 \%)$ and Difco Noble agar (1.2\%). After the addition of agar overlay, rubber stoppers of plaque bottles were changed to sterile cotton plugs and the bottles were placed at $36 \mathrm{C}$ in a $\mathrm{CO}_{2}$ incubator. A second agar overlay $(2 \mathrm{ml})$, the same as the first, was added after four days of incubation. On the eighth day the third agar overlay $(2 \mathrm{ml}$, the same as the first agar overlay except that it contained $0.01 \%$ of neutral red) was added and the bottles (or Petri dishes) were further incubated in the $\mathrm{CO}_{2}$ incubator. Plaques became visible on the tenth day and completely clear on the twelveth. The number and size of plaques increased a little 
by the fourteenth day after which no marked increase in plaque number was observed, though the plaques grew continuously to a confluent state. The plaques on the fourteenth day were counted and PFU was calculated. The influence of the adsorption time is shown in Table 2, which also shows the progression of plaque formation. The appearance of plaques is shown in Fig. 3 and a dose response curve is shown in Fig. 4.

Before the establishment of the above method, the plaque assay in rubber-stoppered plaque bottles was tried in various ways. The following facts were confirmed through

Table 2. Plaque titration of adenovirus 12 in HEK

Adsorption time and increase in plaque counts

\begin{tabular}{|c|c|c|c|c|c|}
\hline \multirow{2}{*}{ Adsorption time } & \multirow{2}{*}{ Dilution of inocula } & \multicolumn{2}{|c|}{ Plaque counts } & \multicolumn{2}{|c|}{$\mathrm{PFU} / 0.2 \mathrm{ml}$} \\
\hline & & 12 days & 14 days & Per dil. & Average \\
\hline $1 \mathrm{hr}$ & $\begin{array}{l}1: 10^{5} \\
1: 4 \times 10^{5}\end{array}$ & $\begin{array}{c}20.3^{*} \\
5.3^{3}\end{array}$ & $\begin{array}{r}21.3 \\
6.6\end{array}$ & $\begin{array}{l}10^{6.4} \\
10^{6.5}\end{array}$ & $10^{6.4}$ \\
\hline $2 \mathrm{hr}$ & $\begin{array}{l}1: 10^{5} \\
1: 4 \times 10^{5}\end{array}$ & $\begin{array}{r}36.0 \\
7.6\end{array}$ & $\begin{array}{r}36.3 \\
9.0\end{array}$ & $\begin{array}{l}10^{6.6} \\
10^{6.6}\end{array}$ & $10^{6.6}$ \\
\hline $4 \mathrm{hr}$ & $\begin{array}{l}1: 10^{5} \\
1: 4 \times 10^{5}\end{array}$ & $\begin{array}{l}43.0 \\
14.3\end{array}$ & $\begin{array}{l}44.5 \\
14.3\end{array}$ & $\begin{array}{l}10^{6.7} \\
10^{6.8}\end{array}$ & $10^{6.7}$ \\
\hline Size of plaque & & $2 \sim 3 \mathrm{~mm}$ & $2 \sim 4 \mathrm{~mm}$ & & \\
\hline
\end{tabular}

Virus: Adenovirus 12 Huie strain $\$ 26$

*Number of plaques per bottle (average of three or four bottles)

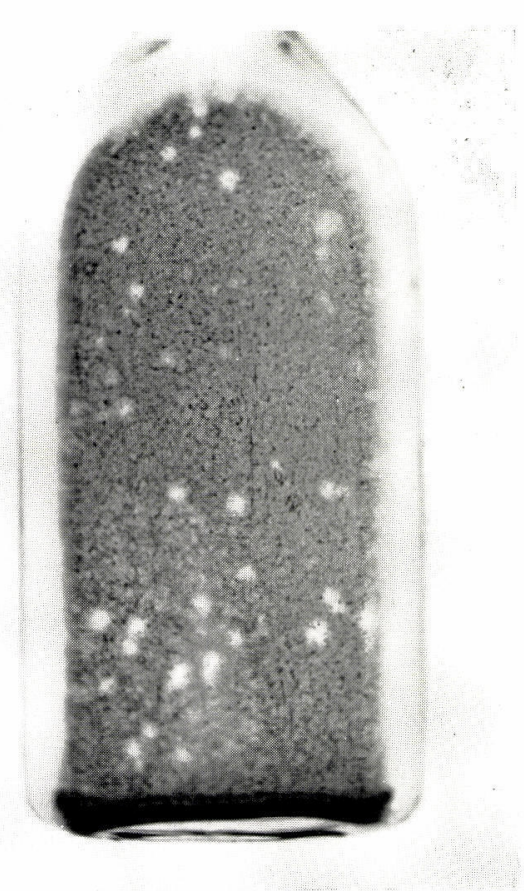

Fig. 3. Plaques of Ad 12 in HEK. 


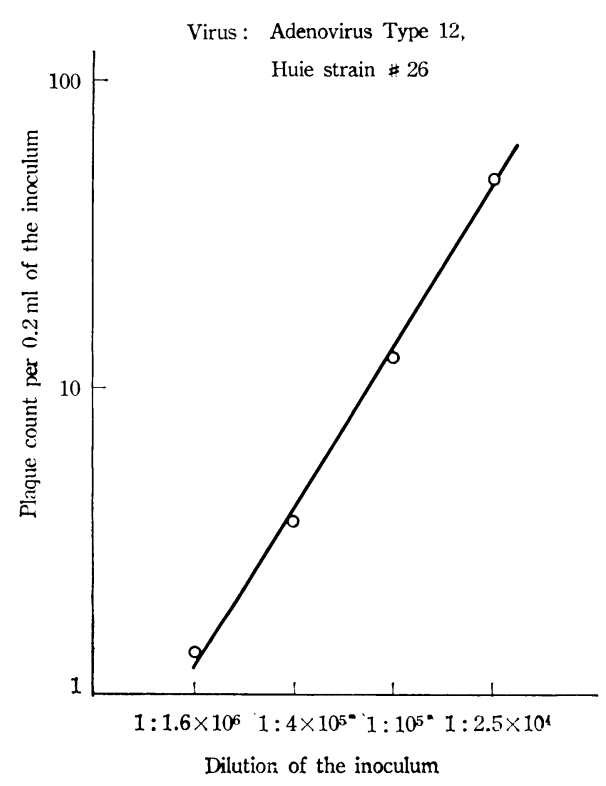

Fig. 4. Plaque titration in HEK. (Dose response curve)

these examinations. Agar was the critical factor for the plaque formation. With Bacto agar (Difco) no plaque was formed but plaques could be formed with Noble agar (Difco). DEAE dextran, which antagonizes agar inhibitor, did not enhance the plaque formation of Ad 12 in HEK. As for the serum, inhibitor frie calf serum was found the best as far as tested but it could be substituted by $10 \%$ skim milk solution (sterilized at $100 \mathrm{C}$ ) when the condition of HEK was fairly good. Chicken serum could also be used for the plaque assay but it sometimes brought about non-specific degeneration of HEK and could not be adopted in the routine titration. When the plaque assay was carried out in rubber-stoppered plaque bottles, plaques appeared on the twelveth day and continued to develop slowly till the eighteenth or nineteenth day. The number of plaques must, therefore, be counted on the twentieth or twentyfirst day. The long period of observation increased the difficulty of the plaque assay because the maintenance of HEK was rather difficult and some plaques, which appeared earlier, became very large (over $10 \mathrm{~mm}$ in diameter) while the other plaques, which appeared later, were small. After comparing the plaque assay in rubber-stoppered bottles with that in cotton-plugged bottles or Petri dishes placed in a $\mathrm{CO}_{2}$ incubator, it was found that the latter method was much more rapid and uniform. The former method was, therefore, discontinued.

\section{Virus Yields in Various Cell Systems}

The virus yields of Ad 12 in various cell systems were compared (Table 3). HEK seemed a little superior and a medium with bicarbonate concentration $(0.15 \%$ ) seemed to enhance the virus yield. It could also be understood that cell lines such as 
HeLa or KB cells were good yielders of Ad 12, although they were far less sensitive than HEK in the titration.

Table 3. Virus yield in various condition

\begin{tabular}{|c|c|c|c|c|}
\hline \multirow{2}{*}{ Cells } & \multicolumn{3}{|c|}{ Media } & \multirow{2}{*}{ Yield } \\
\hline & Base & Sera & Bica. (\%) & \\
\hline \multirow{3}{*}{$\mathrm{KB}$} & $\begin{array}{l}\mathrm{E} \\
\mathrm{E} \\
\mathrm{E}\end{array}$ & - & $\begin{array}{l}0.15 \\
0.075 \\
0.04\end{array}$ & $\begin{array}{l}6.0 \\
6.0 \\
5.3\end{array}$ \\
\hline & $\begin{array}{l}\mathrm{E} \\
\mathrm{E} \\
\mathrm{E}\end{array}$ & $\begin{array}{l}\mathrm{Ch} \\
\mathrm{Ch} \\
\mathrm{Ch}\end{array}$ & $\begin{array}{l}0.15 \\
0.075 \\
0.04\end{array}$ & $\begin{array}{r}6.0 \\
6.5 \\
\leqq 5.0\end{array}$ \\
\hline & $\begin{array}{l}\mathrm{E} \\
\mathrm{E} \\
\mathrm{E}\end{array}$ & $\begin{array}{l}\mathrm{B} \\
\mathrm{B} \\
\mathrm{B}\end{array}$ & $\begin{array}{l}0.15 \\
0.075 \\
0.04\end{array}$ & $\begin{array}{l}6.3 \\
6.0 \\
5.7\end{array}$ \\
\hline \multirow{3}{*}{ HEK } & $\begin{array}{l}E \\
E \\
E\end{array}$ & $=$ & $\begin{array}{l}0.15 \\
0.075 \\
0.04\end{array}$ & $\begin{array}{l}7.0 \\
6.0 \\
6.7\end{array}$ \\
\hline & $\begin{array}{l}\mathrm{E} \\
\mathrm{E} \\
\mathrm{E}\end{array}$ & $\begin{array}{l}\text { Ch } \\
\text { Ch } \\
\text { Ch }\end{array}$ & $\begin{array}{l}0.15 \\
0.075 \\
0.04\end{array}$ & $\begin{array}{l}7.0 \\
6.5 \\
6.7\end{array}$ \\
\hline & $\begin{array}{l}\mathrm{E} \\
\mathrm{E}\end{array}$ & $\begin{array}{l}\mathrm{B} \\
\mathrm{B}\end{array}$ & $\begin{array}{l}0.15 \\
0.075\end{array}$ & $\begin{array}{l}6.7 \\
6.5\end{array}$ \\
\hline \multirow{3}{*}{$\mathrm{HeLa}$} & $\begin{array}{l}\mathrm{E} \\
\mathrm{E} \\
\mathrm{E}\end{array}$ & E & $\begin{array}{l}0.15 \\
0.075 \\
0.04\end{array}$ & $\begin{array}{r}5.5 \\
<4.7 \\
<5.3\end{array}$ \\
\hline & $\begin{array}{l}\mathrm{E} \\
\mathrm{E} \\
\mathrm{E}\end{array}$ & $\begin{array}{l}\text { Ch } \\
\text { Ch } \\
\text { Ch }\end{array}$ & $\begin{array}{l}0.15 \\
0.075 \\
0.04\end{array}$ & $\begin{array}{l}6.3 \\
6.3 \\
5.7\end{array}$ \\
\hline & $\begin{array}{l}\mathrm{E} \\
\mathrm{E} \\
\mathrm{E}\end{array}$ & $\begin{array}{l}\mathrm{B} \\
\mathrm{B} \\
\mathrm{B}\end{array}$ & $\begin{array}{l}0.15 \\
0.075 \\
0.04\end{array}$ & $\begin{array}{l}6.0 \\
5.7 \\
5.3\end{array}$ \\
\hline MK & $\begin{array}{l}199 \\
199 \\
199\end{array}$ & E & $\begin{array}{l}0.075 \\
0.075 \\
0.075\end{array}$ & $\begin{array}{l}4.2(\$ 7) \\
4.0(\$ 9) \\
4.5(\$ 13)\end{array}$ \\
\hline
\end{tabular}

Yield: $\log \mathrm{TCID}_{50} / 0.2 \mathrm{ml}$

E : Eagle's MEM

$\mathrm{Ch}$ : Chicken serum $2 \%$

B : Bovine serum $2 \%$

MK : Monkey kidney cell cueture

\section{DISCUSSION}

The sensitive and reliable titration of Ad 12 and Ad 18 could only be carried out by the use of HEK and could not be performed in cell lines such as HeLa cells, nor in cell cultures such as human diploid cells, originated from a human fetal lung or a human fetal skin-muscle, nor in primary cell cultures such as monkey kidney cells. HeLa cells or KB cells showed a marked CPE when infected with a high multiplicity of the virus and were good yielders of the virus. The difference in 
sensitivity of the CPE appearance between HEK and HeLa cells may be due, in part, to technical difficulties. Because HeLa cells could not be maintained long enough, especially in the absence of serum in the maintenance medium, only a rapid CPE following the infection of a high multiplicity could be observed. The slow CPE, following the infection of a low multiplicity, could not be differentiated from nonspecific cell degenerations.

Apart from these technical problems, there may be an intrinsic phenomenon of Ad 12 infection. Some cell cultures, such as primary cultures of human skin-muscle cells, could be maintained long enough but no marked CPE was observed when they were infected with high dilutions of the virus. Although virus yields in these CPE insensitive cell cultures have not been examined accurately, such CPE insensitive virus yielding infection seems to be an intermediate between the CPE sensitive virus yielding infection (HEK etc.) and the CPE insensitive virus non-yielding infection observed in hamster cell cultures (Shimojo et al., 1966).

Appreciation: The authors experess their appreciation to doctors of the maternity hospitals for the supply of human kidney tissues and to Dr. I. Tagaya for the support of this study.

\section{REFERENCES}

EAGLE, H. (1959) : Amino acid metabolism in mammalian cell cultures. Science, 130, 432-437.

Huebner, R. J., Rowe, W. P., Turner, H. C. And Lane, W. T. (1963): Specific adenovirus complement-fixing antigens in virus-free hamster and rat tumors. Proc. Nat. Acad. Sci., 50, $379-389$.

MCBRIDE, W. D. AND WIENFR, A. (1964): In vitro transfomation of hamster kidney cells by human adenovirus type 12. Proc. Soc. Exptl. Biol. Med., 115, 870-874.

Shimojo, H., Yamamoto, H., Yoshikawa, E. AND Yamashita, T. (1966): The natures of tumor antigen of adenovirus type 12 and its formation in cultured cells after infection. Japan. J. Med. Sci. Biol., 19, 9-22.

Trentin, J. J., YABE, Y, AND TAYloR, G. (1962): The quest for human cancer viruses. Science, $137,835-841$. 